\title{
Nitric oxide induced by polyamines involves antioxidant systems against chilling stress in tomato (Lycopersicon esculentum Mill.) seedling *\#
}

\author{
Qian-nan DIAO ${ }^{\S}$, Yong-jun SONG ${ }^{\S}$, Dong-mei SHI, Hong-yan $\mathrm{QI}^{\dagger}$ \\ (Collaborative Innovation Center of Protected Vegetable Surround Bohai Gulf Region, Key Laboratory of Protected Horticulture of \\ Ministry of Education and Liaoning Province, College of Horticulture, Shenyang Agricultural University, Shenyang 110866, China) \\ †E-mail: hyqiaaa@126.com \\ Received Mar. 4, 2016; Revision accepted May 20, 2016; Crosschecked Nov. 7, 2016
}

\begin{abstract}
Polyamines (PAs) and nitric oxide (NO) are vital signals in modulating plant response to abiotic stress. However, to our knowledge, studies on the relationship between NO and PAs in response to cold stress in tomato are limited. Accordingly, in this study, we investigated the effects of putrescine (Put) and spermidine (Spd) on NO generation and the function of Spd-induced NO in the tolerance of tomato seedling under chilling stress. Spd increased NO release via the nitric oxide synthase (NOS)-like and nitrate reductase (NR) enzymatic pathways in the seedlings, whereas Put had no such effect. Moreover, $\mathrm{H}_{2} \mathrm{O}_{2}$ might act as an upstream signal to stimulate NO production. Both exogenous NO donor (sodium nitroprusside (SNP)) and Spd enhanced chilling tolerance in tomato, thereby protecting the photosynthetic system from damage. Compared to chilling treatment alone, Spd enhanced the gene expressions of superoxide dismutase (SOD), peroxidase (POD), catalase (CAT), and ascorbate peroxidase (APX), and their enzyme activities in tomato leaves. However, a scavenger or inhibitor of NO abolished Spd-induced chilling tolerance and blocked the increased expression and activity due to Spd of these antioxidant enzymes in tomato leaves under chilling stress. The results showed that NO induced by Spd plays a crucial role in tomato's response to chilling stress.
\end{abstract}

Key words: Antioxidant enzymes, Chilling tolerance, Hydrogen peroxide, Nitric oxide, Spermidine, Tomato http://dx.doi.org/10.1631/jzus.B1600102 CLC number: S641.2

\section{Introduction}

Polyamines (PAs), mainly putrescine (Put), spermidine (Spd), and spermine (Spm), are a group of phytohormone-like aliphatic amine compounds. PAs exert influence in the plant life cycle, including cell division and elongation, morphogenesis, seed germination, flowering, and senescence (Igarashi and Kashiwagi, 2000; Bais and Ravishankar, 2002; Yoda

\footnotetext{
* Corresponding author

$\S$ The two authors contributed equally to this work

* Project supported by the China Agriculture Research System (No. CARS-25) and the Liaoning Innovative Research Team in University (No. LZ2015025), China

\# Electronic supplementary materials: The online version of this article (http://dx.doi.org/10.1631/jzus.B1600102) contains supplementary materials, which are available to authorized users

(B) ORCID: Qian-nan DIAO, http://orcid.org/0000-0001-5086-5166

(C) Zhejiang University and Springer-Verlag Berlin Heidelberg 2016
}

et al., 2006; Wimalasekera et al., 2011; Gupta et al., 2013). Furthermore, PAs also have impact on plants in response to diverse abiotic stresses, such as salinity (Zapata et al., 2004; Shu et al., 2012), drought (Yang et al., 2007; Li et al., 2015), oxidative stress (Rider et al., 2007; Puyang et al., 2015), high temperature (Cheng et al., 2012; Mostofa et al., 2014), and chilling stress (Nayyar, 2005; Yamamoto et al., 2012). It was previously suggested that the elevated stress tolerance of plants due to PAs may be attributed to their polycationic nature at physiologic $\mathrm{pH}$. PAs can interact with negatively charged macromolecules, which inhibits the phase change under stressed condition (Groppa and Benavides, 2008; Alcázar et al., 2010). Additionally, PAs can directly or indirectly scavenge reactive oxygen species (ROS) and enhance the activities of antioxidant enzymes (Verma and Mishra, 2005; Parvin et al., 2014). 
Nitric oxide (NO) is a highly reactive gaseous molecule that regulates diverse plant growth and development processes, including seed germination, root growth, flowering, and senescence (Neill et al., 2003; Besson-Bard et al., 2008). Several studies have suggested that $\mathrm{NO}$ can participate in controlling the various plant responses toward diverse abiotic stresses. For example, Esim and Atici (2014) observed that exogenous NO (sodium nitroprusside (SNP)) can effectively alleviate chilling stress damage in maize seedlings. Tian and Lei (2006) reported that NO treatment improved the growth of wheat seedlings and relieved oxidative damage. In contrast, according to Tun et al. (2006), PAs induced accumulation of NO in Arabidopsis thaliana seedlings. Arasimowicz-Jelonek et al. (2009) presented evidence that PAs promoted NO synthesis in cucumber seedlings during drought stress. In light of the common functions of PAs and NO in abiotic stresses, it can be conjectured that NO is linked to PA-induced stress responses (Wimalasekera et al., 2011).

Many potential sources of NO production exist in plants; among them, the nitric oxide synthase (NOS) and nitrate reductase (NR) enzymatic pathways have been the focus of most studies (Guo et al., 2003; Wimalasekera et al., 2011). NR has been found to be the source of NO in Arabidopsis, tobacco, sunflower, alfalfa, spinach, and maize (Desikan et al., 2002; Rockel et al., 2002; Dordas et al., 2003; Planchet et al., 2005). In animals, NO is synthesized via NOS. Although mammalian-type NOS is intricate (Guo et al., 2003; Zemojtel et al., 2006), NOS-like activity has been found extensively in plants, and inhibitors of mammalian NOS can suppress NO production in plants (Neill et al., 2008; Tewari et al., 2013). NO and hydrogen peroxide $\left(\mathrm{H}_{2} \mathrm{O}_{2}\right)$, as universal signal transduction molecules, have been shown to be involved in controlling many physiological functions in plants (Finkel and Holbrook, 2000; Bright et al., 2006; Dickinson and Chang, 2011). A growing number of studies show that there is a relationship between NO and $\mathrm{H}_{2} \mathrm{O}_{2}$. During plant responses to various stresses or stimuli, $\mathrm{NO}$ and $\mathrm{H}_{2} \mathrm{O}_{2}$ production often occur in parallel or in short succession (Bright et al., 2006; Pasqualini et al., 2009). Interestingly, evidence has been found suggesting that $\mathrm{H}_{2} \mathrm{O}_{2}$ can be also generated via PA catabolic pathways, through diamine oxidase (DAO) and polyamine oxidase (PAO) activ- ities (Martin-Tanguy, 2001; Kusano et al., 2007; Hussain et al., 2011; Gupta et al., 2013). In Zea mays, PAO modulates $\mathrm{H}_{2} \mathrm{O}_{2}$ production during wound healing (Angelini et al., 2008). In the development of soybean lateral roots, DAO and PAO play important roles in $\mathrm{H}_{2} \mathrm{O}_{2}$ formation ( $\mathrm{Su}$ et al., 2006).

Chilling is a main abiotic stress factor that directly influences plant growth and productivity. It has been suggested that Put, Spd, and NO have effects on plant responses to chilling stress (Neill et al., 2003; Cuevas et al., 2008; Li et al., 2014). We have recently shown that Put and Spd accumulated to some extent in tomato seedlings in response to low temperature (Song et al., 2015). However, limited studies exist on whether PAs are involved in NO production under chilling stress, or whether PAs can enhance chilling tolerance by inducing NO production. Therefore, we performed a series of experiments using tomato seedlings to clarify these problems. The aims of this study were as follows: (1) to study which type of PAs can induce NO accumulation under chilling stress; (2) to clarify the possible mechanism underlying PA-induced NO synthesis under chilling stress; and (3) to determine whether NO production induced by PAs can enhance chilling tolerance.

\section{Materials and methods}

\subsection{Plant materials, growth, and treatment conditions}

Seeds of tomato (Lycopersicon esculentum Mill. $\mathrm{cv}$. Moneymaker) were germinated and grown in $12 \mathrm{~cm} \times 12 \mathrm{~cm}$ plastic pots containing peat moss in a greenhouse (temperature $25{ }^{\circ} \mathrm{C}$ (day)/ $15{ }^{\circ} \mathrm{C}$ (night), natural light, relative humidity $60 \%$ ) in September 2014 at Shenyang Agricultural University, China. The seedlings were watered daily. The tomato plants at the five-leaf stage were treated as follows.

The seedlings were subjected to three treatments: (1) $\mathrm{H}_{2} \mathrm{O}+$ chilling (as control); (2) $1 \mathrm{mmol} / \mathrm{L} \mathrm{Put}+$ chilling; and (3) $1 \mathrm{mmol} / \mathrm{L} \mathrm{Spd+chilling.} \mathrm{In} \mathrm{order} \mathrm{to}$ carry out chilling treatment, the seedlings were transferred to a phytotron. The environmental conditions were as follows: light irradiation of $600 \mu \mathrm{mol} /\left(\mathrm{m}^{2} \cdot \mathrm{s}\right)$ and temperature of $4{ }^{\circ} \mathrm{C}$. Put and Spd treatments were carried out by spraying over the whole leaves of tomato seedlings (five-leaf-old), which were then 
exposed to $25^{\circ} \mathrm{C}$ (day) $/ 15^{\circ} \mathrm{C}$ (night) for $24 \mathrm{~h}$ before chilling treatment. Samples for physiological and biochemical analyses (including $\mathrm{NO}$ and $\mathrm{H}_{2} \mathrm{O}_{2}$ contents, NR activity, and NOS-like activity) were harvested at 0,12 , and $24 \mathrm{~h}$ after the treatment.

To further investigate whether Spd induced $\mathrm{NO}$, before chilling treatment $\left(4^{\circ} \mathrm{C}\right)$ some seedlings were pretreated with $1 \mathrm{mmol} / \mathrm{L}$ methylglyoxalbis(guanylhydrazone) (MGBG, an inhibitor of Spd synthesis), $200 \mu \mathrm{mol} / \mathrm{L} 2$-phenyl-4,4,5,5-tetramethylimidazoline-1-oxyl-3-oxide (PTIO, a scavenger of NO), or distilled water, and treated with Spd or distilled water $12 \mathrm{~h}$ later. Some seedlings with distilled water treatment at $4{ }^{\circ} \mathrm{C}$ served as the control. The leaves for $\mathrm{NO}$ analysis were harvested at $24 \mathrm{~h}$ after the treatments.

Also, to investigate the effect of Spd on the major enzymatic pathway of NO, some seedlings were treated with distilled water at $4{ }^{\circ} \mathrm{C}$ in a phytotron and used as the control. Other seedlings were treated with distilled water, $200 \mu \mathrm{mol} / \mathrm{L} \mathrm{N}^{\mathrm{G}}$-nitro-L-arginine methyl ester (L-NAME, an inhibitor of NOS), or $200 \mu \mathrm{mol} / \mathrm{L}$ tungstate (an inhibitor of NR); the pretreatment was done from 6:00 p.m. to 6:00 a.m. for $3 \mathrm{~d}$. After $12 \mathrm{~h}$, the seedlings were sprayed with $1 \mathrm{mmol} / \mathrm{L}$ Spd, and then subjected to chilling stress for $24 \mathrm{~h}$.

To investigate whether PAs induced $\mathrm{NO}$ via the production of $\mathrm{H}_{2} \mathrm{O}_{2}$, before chilling treatment these seedlings were treated with catalase (CAT, $100 \mathrm{U} / \mathrm{ml}$; $\mathrm{H}_{2} \mathrm{O}_{2}$ scavenger) or distilled water and then sprayed with Put and Spd $12 \mathrm{~h}$ later, respectively. Some seedlings subjected to distilled water treatment at $4{ }^{\circ} \mathrm{C}$ served as the control. The leaves for $\mathrm{NO}$ analysis were harvested at 12 and $24 \mathrm{~h}$ after the treatments.

To investigate the effect of $\mathrm{NO}$ on $F_{\mathrm{v}} / F_{\mathrm{m}}$ (maximum quantum efficiency of photosystem II (PSII), the ratio of variable fluorescence and maximum fluorescence) and electrolyte leakage, the tomato seedlings were sprayed with $200 \mu \mathrm{mol} / \mathrm{L}$ SNP (an NO donor) for $12 \mathrm{~h}$ daily for $3 \mathrm{~d}$ (the treatments were as described above), and then exposed to chilling stress for $24 \mathrm{~h}$ after a 12 -h pretreatment. Other seedlings were pretreated with distilled water, $200 \mu \mathrm{mol} / \mathrm{L}$ L-NAME, $200 \mu \mathrm{mol} / \mathrm{L}$ tungstate, or $200 \mu \mathrm{mol} / \mathrm{L}$ PTIO. The pretreatment was done for $12 \mathrm{~h}$ daily for $3 \mathrm{~d}$. After $12 \mathrm{~h}$, the seedlings were treated with $1 \mathrm{mmol} / \mathrm{L}$ $\mathrm{Spd}$, and then exposed to chilling stress for $24 \mathrm{~h}$. The seedlings that were subjected to 25 or $4{ }^{\circ} \mathrm{C}$ for $24 \mathrm{~h}$ served as control and chilling control, respectively.
To investigate the effect of $\mathrm{NO}$ in the antioxidant system induced by Spd, the tomato seedlings were sprayed with distilled water, $200 \mu \mathrm{mol} / \mathrm{L}$ L-NAME, $200 \mu \mathrm{mol} / \mathrm{L}$ tungstate, or $200 \mu \mathrm{mol} / \mathrm{L}$ PTIO. After $12 \mathrm{~h}$, the seedlings were treated with $1 \mathrm{mmol} / \mathrm{L} \mathrm{Spd}$ and exposed to chilling stress for $24 \mathrm{~h}$. The seedlings subjected to 25 or $4{ }^{\circ} \mathrm{C}$ for $24 \mathrm{~h}$ served as control and chilling control, respectively.

The third and fourth fully expanded leaves were sampled from 12 uniform tomato seedlings for each treatment. All leaf samples were repeatedly washed with distilled water, then frozen in liquid $\mathrm{N}_{2}$, and stored at $-80^{\circ} \mathrm{C}$ for subsequent analysis.

\subsection{Determination of electrolyte leakage}

Electrolyte leakage was measured based on the method of Sairam and Srivastava (2002). Leaf samples $(0.2 \mathrm{~g})$ were rinsed three times with deionized water and placed in $20 \mathrm{ml}$ distilled water at $25^{\circ} \mathrm{C}$ for $3 \mathrm{~h}$, and the initial electrical conductivity of the solution $\left(E_{1}\right)$ was measured. Leaves were incubated at $100{ }^{\circ} \mathrm{C}$ for $30 \mathrm{~min}$ and cooled to room temperature, and then the final electrical conductivity $\left(E_{2}\right)$ was measured. The relative electrolyte leakage was determined as $E_{1} / E_{2}$ and expressed as percent.

\subsection{NO release determination}

NO content was measured by the method of Murphy and Noack (1994) with slight modifications. Leaf samples $(0.5 \mathrm{~g})$ were placed in $100 \mathrm{U}$ of CAT and $100 \mathrm{U}$ of SOD for $5 \mathrm{~min}$ to remove endogenous ROS before adding $10 \mathrm{ml}$ of $5 \mathrm{mmol} / \mathrm{L}$ oxyhemoglobin $\left(\mathrm{HbO}_{2}\right)$. After incubation, $\mathrm{NO}$ was determined by assaying the conversion of $\mathrm{HbO}_{2}$ to methemoglobin (metHb), and the NO content was estimated by using the formula of $\varepsilon\left(A_{401(\mathrm{metHb})}-A_{421\left(\mathrm{HbO}_{2}\right)}\right)$, where $\varepsilon$ is extinction coefficient of $77 \mathrm{ml} /(\mathrm{mol} \cdot \mathrm{cm})$, and $A_{401}(\mathrm{metHb})$ and $A_{421}\left(\mathrm{HbO}_{2}\right)$ are the absorbance of metHb at $401 \mathrm{~nm}$ and $\mathrm{HbO}_{2}$ at $421 \mathrm{~nm}$, respectively.

\subsection{NO detection by confocal microscopy}

NO detection was carried out according to Corpas et al. (2006) with small modifications, by binding to the cell-permeable, NO-sensitive fluorescent dye 3-amino, 4-aminomethyl-2',7'-difluorescein diacetate (DAF-FM DA, Beyotime). Epidermal fragments of tomato were incubated in $1 \mathrm{ml}$ of $5 \mu \mathrm{mol} / \mathrm{L}$ DAF-FM DA $(10 \mathrm{mmol} / \mathrm{L}$ Tris- $\mathrm{HCl}$ buffer, $\mathrm{pH} 7.2)$ at $25{ }^{\circ} \mathrm{C}$ for 
$20 \mathrm{~min}$. After washing with fresh loading buffer three times, the fluorescence images of $\mathrm{NO}$ were observed with a Zeiss Axiovert $200 \mathrm{M}$ inverted microscope equipped with a confocal laser scanner (Zeiss LSM 510). Excitation and emission were at 495 and $515 \mathrm{~nm}$, respectively. The Zeiss 2012 software was used to analyze the images.

\subsection{Assay of NR activity}

NR activity was measured as described by Scheible et al. (1997) with slight modifications. Leaf samples $(0.5 \mathrm{~g})$ were homogenized in extraction buffer, including $100 \mathrm{mmol} / \mathrm{L}$ HEPES-KOH (pH 7.5), $5 \mathrm{mmol} / \mathrm{L}$ dithiothreitol, $1 \mathrm{mmol} / \mathrm{L}$ ethylenediaminetetraacetic acid (EDTA), $10 \%$ glycerol, $0.1 \%$ $(1 \mathrm{~g} / \mathrm{L})$ Triton X-100, $0.5 \mathrm{mmol} / \mathrm{L}$ phenylmethylsulfonyl fluoride, $1 \mu \mathrm{mol} / \mathrm{L}$ leupeptin, $20 \mu \mathrm{mol} / \mathrm{L}$ flavin adenine dinucleotide, $5 \mu \mathrm{mol} / \mathrm{L} \mathrm{Na}_{2} \mathrm{MoO}_{4}$, and $10 \mathrm{~g} / \mathrm{L}$ polyvinylpolypyrrolidone (PVP). The homogenates were centrifuged at $4{ }^{\circ} \mathrm{C}$ and $10000 \mathrm{~g}$ for $20 \mathrm{~min}$, and then the resulted supernatant was used for NR analysis. The nitrite produced was determined by absorbance at $520 \mathrm{~nm}$.

\subsection{Assay of NOS-like activity}

The NOS-like activity was measured with an NOS colorimetric assay kit (Nanjing Jiancheng Bioengineering Institute, China). Leaf samples $(0.5 \mathrm{~g})$ were homogenized with $2 \mathrm{ml}$ of $50 \mathrm{mmol} / \mathrm{L}$ potassium phosphate buffer $(\mathrm{pH} 7.4,1 \mathrm{mmol} / \mathrm{L}$ leupeptin, $1 \mathrm{mmol} / \mathrm{L}$ EDTA, $10 \mathrm{mmol} / \mathrm{L}$ ethylene glycol-bis( $\beta$ aminoethyl ether)- $N, N, N^{\prime}, N^{\prime}$-tetraacetic acid (EGTA), $1 \mathrm{mmol} / \mathrm{L}$ phenylmethylsulfonyl fluoride (PMSF), $10 \mathrm{~g} / \mathrm{L}$ PVP) and centrifuged at $15000 \mathrm{~g}$ for $20 \mathrm{~min}$; the supernatant was incubated in the assay reagent at $37^{\circ} \mathrm{C}$ for $15 \mathrm{~min}$, which was then terminated by a stop buffer. The absorbance was recorded at $530 \mathrm{~nm}$.

\subsection{Determination of $\mathrm{H}_{2} \mathrm{O}_{2}$ content}

$\mathrm{H}_{2} \mathrm{O}_{2}$ content was quantified by the method of Patterson et al. (1984) with some modifications. Leaf samples $(0.5 \mathrm{~g})$ were homogenized with $3 \mathrm{ml}$ ice-cold acetone. Titanium reagent ( $20 \%$ titanium tetrachloride in concentrated $\mathrm{HCl}$ ) was added to extract the supernatant. An ammonia solution $(0.2 \mathrm{ml}$ at $17 \mathrm{~mol} / \mathrm{L})$ was added in $\mathrm{Ti}-\mathrm{H}_{2} \mathrm{O}_{2}$, centrifuged at $4{ }^{\circ} \mathrm{C}$ and $30000 \mathrm{~g}$ for $10 \mathrm{~min}$, and the supernatant was discarded. The pellet was washed three times with ice-cold acetone, then drained, and dissolved in $3 \mathrm{ml} 1 \mathrm{~mol} / \mathrm{L}$ $\mathrm{H}_{2} \mathrm{SO}_{4}$. The absorbance of the solution was measured at $410 \mathrm{~nm}$.

\subsection{Measurement of chlorophyll fluorescence}

Chlorophyll fluorescence was measured with a Dual-PAM 100 chlorophyll fluorometer (Walz, Effeltrich, Germany) at room temperature according to the method of Song et al. (2015).

\subsection{Determination of antioxidative enzyme activity}

For the extraction of antioxidative enzymes, leaf samples $(0.5 \mathrm{~g})$ were homogenized with $50 \mathrm{mmol} / \mathrm{L}$ $\mathrm{Na}_{2} \mathrm{HPO}_{4}-\mathrm{NaH}_{2} \mathrm{PO}_{4}$ buffer (pH 7.8) including $0.2 \mathrm{mmol} / \mathrm{L}$ EDTA and $20 \mathrm{~g} / \mathrm{L} \mathrm{PVP}$, and then centrifuged for $20 \mathrm{~min}$ at $12000 \mathrm{~g}$, and the resulting supernatant was used for the assay of enzyme activity. All operations were carried out at the temperature of $0-4{ }^{\circ} \mathrm{C}$. All spectrophotometric analyses were conducted on a UV-vis spectrophotometer (UV-2401, Shimadzu Co., Ltd., Japan).

SOD activity was determined by measuring its ability to inhibit the photochemical reduction of nitro blue tetrazolium (NBT), following the method of Giannopolitis and Ries (1977). POD activity was measured as described by Thomas et al. (1982). The reaction mixture contained $3 \mathrm{ml}$ of phosphate buffer (pH 7.0), $1.0 \mathrm{ml}$ of $0.18 \% \mathrm{H}_{2} \mathrm{O}_{2}, 1.0 \mathrm{ml}$ of enzyme extract, and $1.0 \mathrm{ml}$ of $0.1 \%$ guaiacol. CAT activity was assayed by the method of Cakmak and Marschner (1992). The decomposition of $\mathrm{H}_{2} \mathrm{O}_{2}$ was observed as a decrease in absorbance at $240 \mathrm{~nm}$. APX activity was measured following the description of Nakano and Asada (1981) by measuring the rate of ascorbate oxidation at $290 \mathrm{~nm}$.

In all enzyme preparations, protein concentration was determined according to the method of Bradford (1976); bovine serum albumin (BSA; Sigma) was used as standard.

\subsection{Total RNA extraction and gene expression analysis}

Total RNA was extracted with the RNAprep pure plant total RNA extraction kit (Kangwei, Beijing, China). The complementary DNA (cDNA) synthesis was carried out according to the manufacturer's instructions (Tiangen, China). Primer 3.0 was used for primer design. The polymerase chain reaction (PCR) primer sequences are listed in Table 1. Real-time PCR 
Table 1 Accession numbers and primer sequences of the analyzed genes in this study

\begin{tabular}{|c|c|c|c|}
\hline Category & Accession No. & $\begin{array}{l}\text { Encode corresponding } \\
\text { enzyme }\end{array}$ & Primer sequence \\
\hline \multirow[t]{2}{*}{$\mathrm{Cu} / \mathrm{Zn}-\mathrm{SOD}$} & AF034411.1 & SOD & F: 5'-ACCACAACCAGCACTACCAAT-3' \\
\hline & & & R: 5'-GTCCAGGAGCAAGTCCAGTTA-3' \\
\hline \multirow[t]{2}{*}{ cat1 } & M93719.1 & CAT & F: 5'-GATGAGCACACTTTGGAGCA-3' \\
\hline & & & R: 5'-TGCCCTTCTATTGTGGTTCC-3' \\
\hline \multirow[t]{2}{*}{$A P X$} & NM_001247702 & APX & F: 5'-CCACTTGAGGGACGTGTTTG-3' \\
\hline & & & R: 5'-CCACTTGAGGGACGTGTTTG-3' \\
\hline \multirow[t]{2}{*}{ cevil6 } & NM 001247041.2 & POD & F: 5'-ACAGCTCCTCCGAATTCCAA-3' \\
\hline & & & R: 5'-GGAATCACGAGCAGCAAGAG-3' \\
\hline \multirow[t]{2}{*}{$T P X 1$} & NM_001247242.1 & POD & F: 5'-GAGATGCAGTTGTGGCTACG-3' \\
\hline & & & R: 5'-GCGAAGGATTGTTGCAGTCT-3' \\
\hline \multirow[t]{2}{*}{$T P X 2$} & NM_001247715.2 & POD & F: 5'-AGCGGGTTCTAGCTATGGTC-3' \\
\hline & & & R: 5'-AAGAGATGGAGCGTTTGGGA-3' \\
\hline \multirow[t]{2}{*}{ Actin } & Q96483 & Reference gene & F: 5'-TGTCCCTATTTACGAGGGTTATGC-3' \\
\hline & & & R: 5'-AGTTAAATCACGACCAGCAAGAT-3' \\
\hline
\end{tabular}

F: forward; R: reverse

analysis was performed on ABI 7500 (Applied Biosystems, USA) by using the SYBR Green PCR Real Master Mix (Tiangen, China). The $2^{-\Delta \Delta C_{\mathrm{T}}}$ method was used to measure relative expression of gene, and the threshold cycle $\left(C_{\mathrm{T}}\right)$ value was normalized to actin.

\subsection{Statistical analysis}

Two independent experiments were performed with three replicates in each treatment. Data used Duncan's multiple range tests at the 0.05 level of significance. The charts were made by using Origin 8.0.

\section{Results and discussion}

\subsection{Exogenous Spd-induced NO production in tomato leaves under chilling stress}

$\mathrm{NO}$ as a signaling molecule in plant was found as late as 1998 (Delledonne et al., 1998). A growing number of studies have indicated that NO is involved in plant's stress response (Siddiqui et al., 2011). PAs have also been known to increase NO generation. However, the actual reaction mechanism has not been solved. Yamasaki and Cohen (2006) have indicated that PAs can induce NO generation through an uncertain pathway. Here, we describe the correlation of NO production with PAs in tomato leaves under chilling stress.

Under chilling stress, exogenous Spd treatment greatly increased the NO content at 12 and $24 \mathrm{~h}$ compared to control. However, compared to control, there was no change in the NO content with Put treatment (Figs. 1a and 1b). To further confirm whether Spd had this effect, we analyzed the levels of
NO with MGBG and PTIO pretreatments (Bais and Ravishankar, 2002; He et al., 2002; ArasimowiczJelonek et al., 2009; Gong et al., 2014) before Spd application. Both MGBG and PTIO reduced the NO content induced by Spd under chilling stress (Figs. 1c and 1d). Hence, we concluded that Spd could induce NO production in tomato leaves under chilling stress. In accordance with our results, Tun et al. (2006) reported a correlation between PAs and NO biosynthesis in Arabidopsis seedlings, in which Spd induced NO production, whereas Put had very little effect. However, Silveira et al. (2006) reported that Put enhanced NO production in the embryogenic culture of Araucaria angustifolia. Therefore, the effect of PAs on NO may depend on the species, types, and stress conditions.

\subsection{NOS and NR pathways involved in Spd-induced NO synthesis in tomato leaves under chilling stress}

In plants, NOS-like and NR enzymes have been suggested to be the two major sources of NO accumulation (Guan et al., 2014). Since Ninnemann and Maier (1996) first identified the existence of NOS-like enzyme activity in plants, a growing number of studies have indicated that NOS-like activity is detectable in different plant species (del Río et al., 2004). NOS-like enzyme could produce NO through the oxidation of L-arginine (Guo et al., 2003; Neill et al., 2003). With the exception of NOS-like enzyme, the well documented route for NO in plants is the NR pathway, which is located in the cytosol and catalyzes the reduction of nitrate to nitrite by NADH (Gupta et al., 2011). In our study, the NOS-like and NR activities were both increased by Spd treatment, 

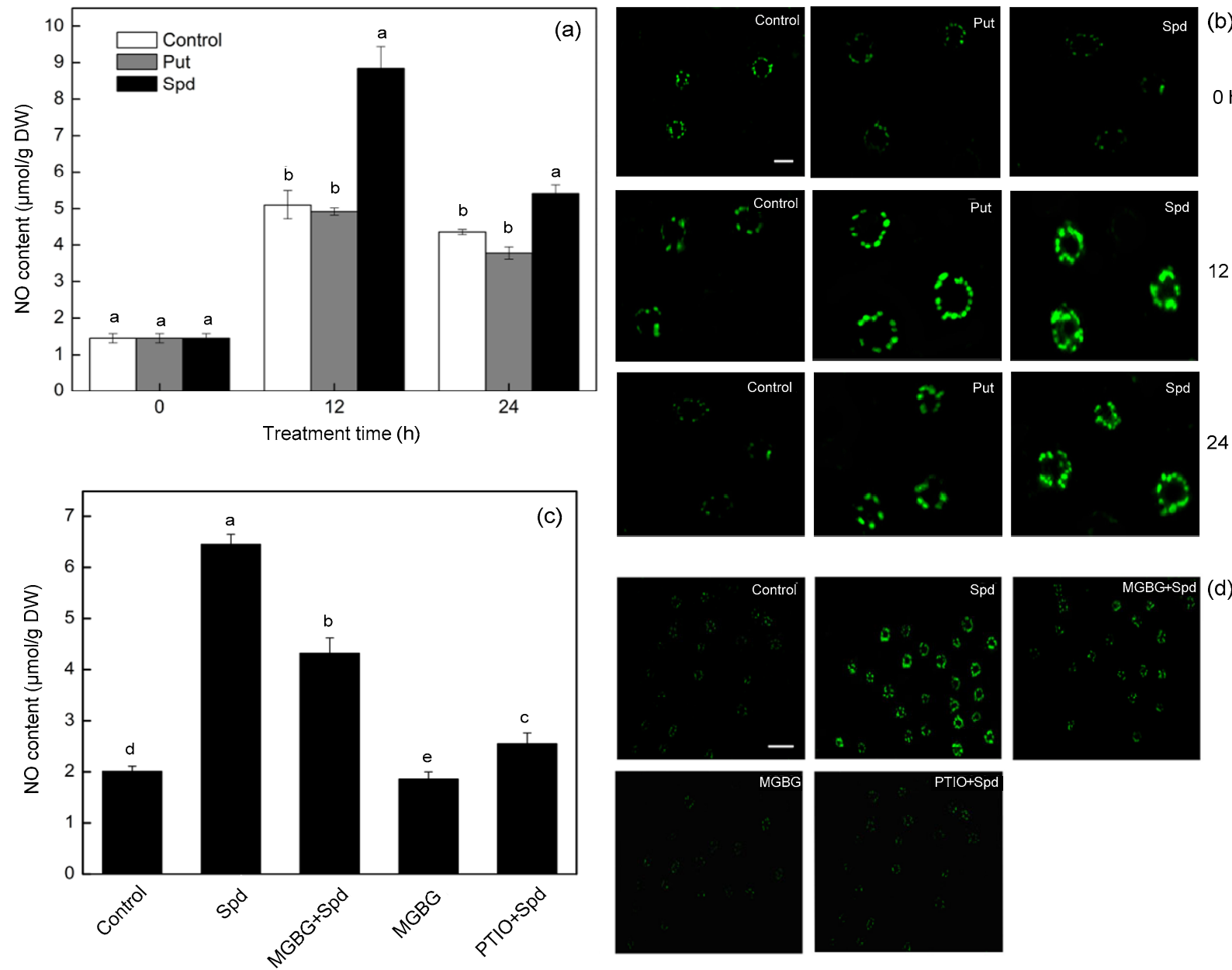

(b)
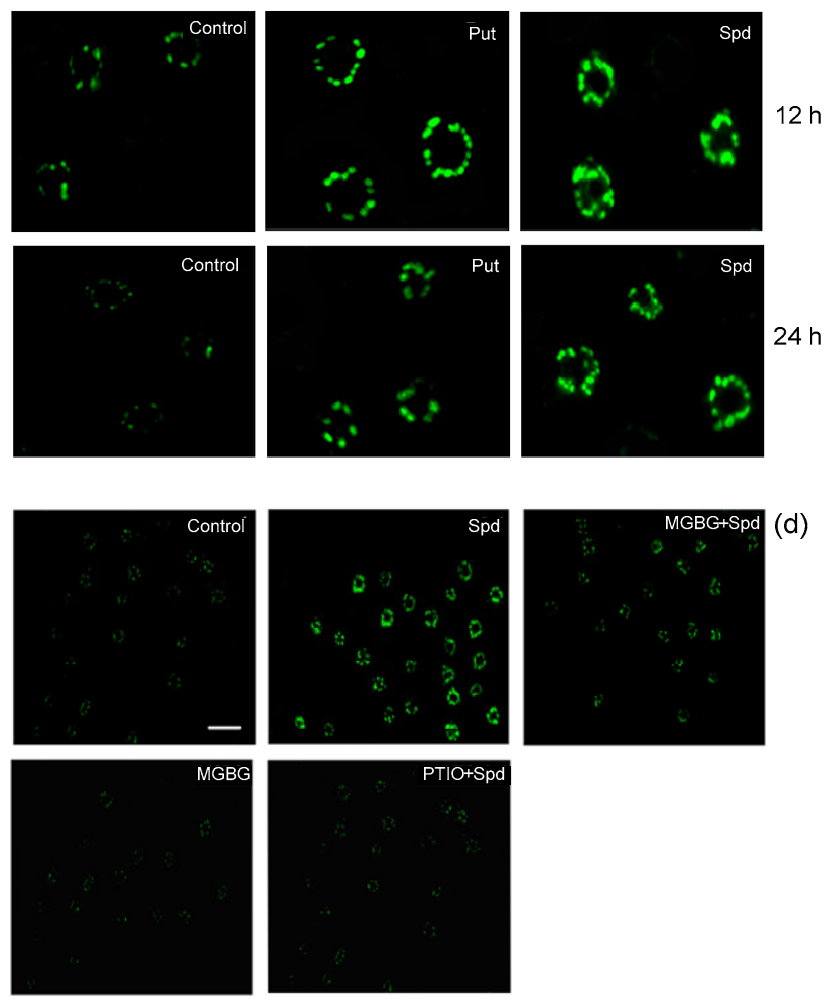

Fig. 1 NO accumulation induced by PAs

(a) Tomato seedlings were applied with PAs $(1 \mathrm{mmol} / \mathrm{L}$ Put and $1 \mathrm{mmol} / \mathrm{L} \mathrm{Spd}$ ) or distilled water (control). The samples were harvested for analysis of NO content during chilling stress $\left(4^{\circ} \mathrm{C} ; 0,12\right.$, and $24 \mathrm{~h}$ ). (b) Fluorescence images of NO in tomato leaves by the NO-selective fluorochrome DAF-FM DA. Scale bar for NO accumulation represents $25 \mu \mathrm{m}$. (c) To further investigate the effect of Spd on NO content, some seedlings were pretreated with $1 \mathrm{mmol} / \mathrm{L}$ MGBG (an inhibitor of Spd synthesis) $12 \mathrm{~h}$ before chilling treatment; other seedlings were pretreated with $1 \mathrm{mmol} / \mathrm{L}$ MGBG, $200 \mu \mathrm{mol} / \mathrm{L} \mathrm{PTIO}$ (a scavenger of $\mathrm{NO}$ ), or distilled water, and then sprayed with Spd $12 \mathrm{~h}$ later. The seedling leaves for NO analysis with various treatments were harvested at $24 \mathrm{~h}$ under chilling stress. (d) Fluorescence images of NO in tomato leaves by the NO-selective fluorochrome DAF-FM DA. Scale bar for NO accumulation represents $60 \mu \mathrm{m}$. Data are expressed as mean \pm standard error (SE), with $n=3$. Different letters denote significant differences at $P \leq 0.05$ according to Duncan's multiple range tests

compared to control. However, the application of Put did not have this effect (Figs. 2a and 2b). Rosales et al. (2012) found that PAs can regulate the combination of 14-3-3 proteins with the $\mathrm{H}^{+}$-ATPase, thereby inducing NR activity. Tanou et al. (2014) indicated that $\mathrm{Spm}$ can increase the relative expression of leNR in citrus under salinity stress. In addition, compared to control, treatment with Spd increased transcript levels of leNR in tomato, but exogenous Put did not alter leNR expression under chilling stress. Application of Put and Spd reduced leNOS1 relative expression compared to control (Fig. S1 and Table S1). The leNOS1 expression was inconsistent with NOS-like activity, most probably due to an uncertain gene, but in most cases the genes were predicted. Therefore, it still needs to be clarified whether they did encode relative genes or affect enzyme synthesis. Furthermore, we also examined the contents of $\mathrm{NO}$ in tomato leaves after treatment with tungstate, an inhibitor of NR, and L-NAME, an inhibitor of NOS (Besson-Bard et al., 2009; Xiong et al., 2012; Alemayehu et al., 2015; Sun et al., 2015). In this experiment, the two inhibitors 

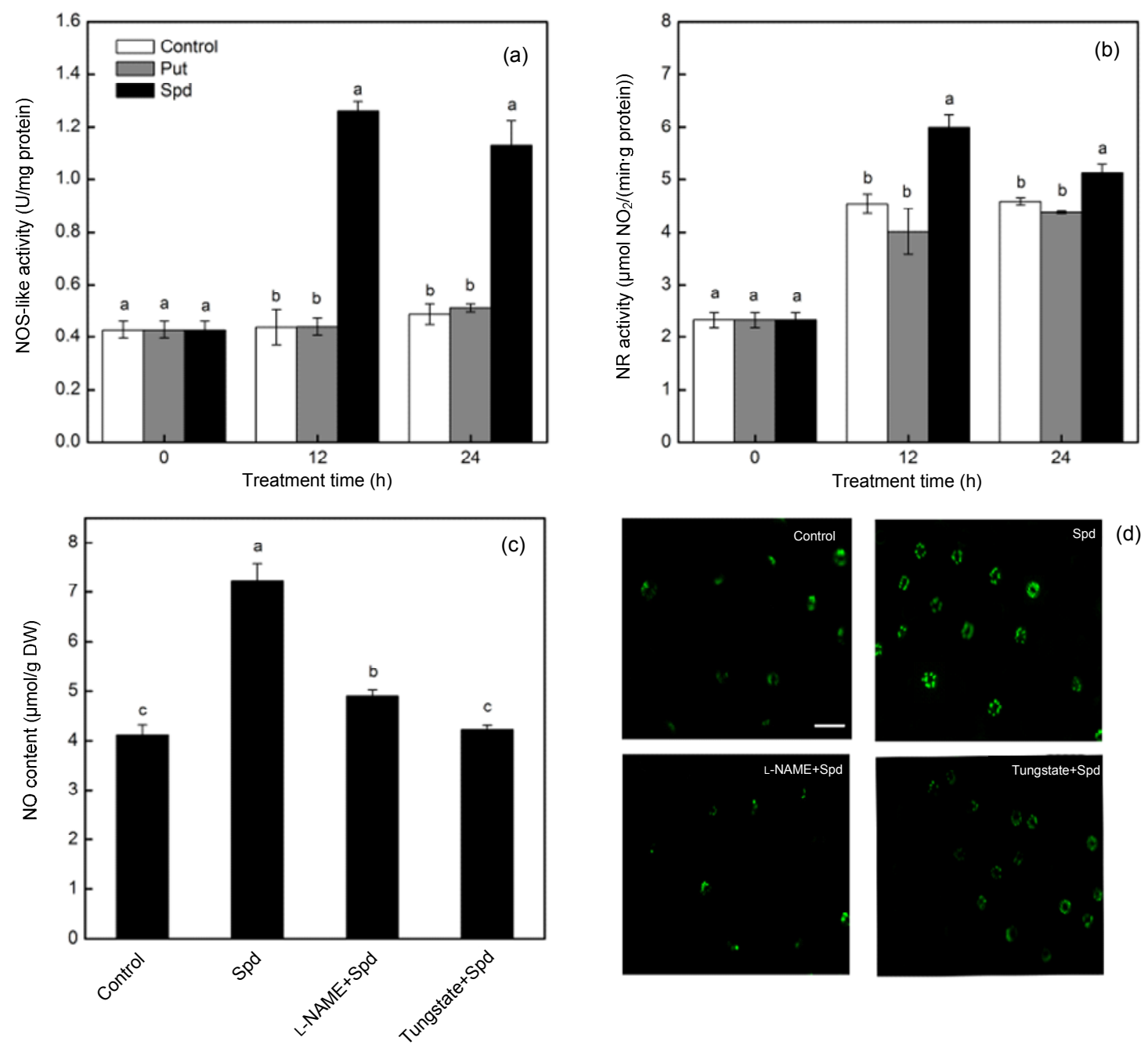

(d)
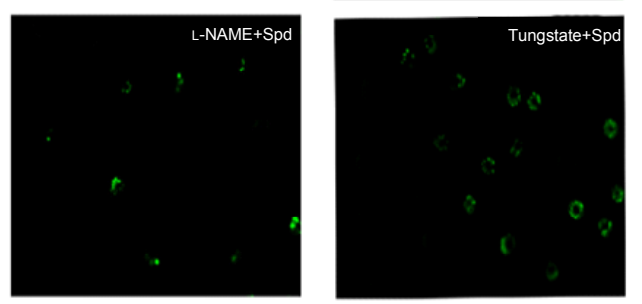

Fig. 2 Involvement of NOS-like and NR in PA-induced NO generation

(a) Tomato seedlings were treated with PAs $(1 \mathrm{mmol} / \mathrm{L}$ Put and $1 \mathrm{mmol} / \mathrm{L} \mathrm{Spd})$ and distilled water (control). The samples were harvested for analysis of NOS-like activity during chilling stress $\left(4^{\circ} \mathrm{C} ; 0,12\right.$, and $24 \mathrm{~h}$ ). (b) Analysis of NR activity during chilling stress. (c) Some seedlings with distilled water treatment at $4{ }^{\circ} \mathrm{C}$ were used as control. Other seedlings were pretreated with distilled water, $200 \mu \mathrm{mol} / \mathrm{L} \mathrm{L-NAME} \mathrm{(an} \mathrm{inhibitor} \mathrm{of} \mathrm{NOS),} \mathrm{or} 200 \mu \mathrm{mol} / \mathrm{L}$ tungstate (an inhibitor of NR). After $12 \mathrm{~h}$, the seedlings were treated with $1 \mathrm{mmol} / \mathrm{L} \mathrm{Spd}$, and then exposed to chilling stress at $4{ }^{\circ} \mathrm{C}$ for $24 \mathrm{~h}$. The seedlings' leaves for NO analysis were harvested at $24 \mathrm{~h}$ during chilling stress. (d) Fluorescence images of NO in tomato leaves by the NO selective fluorochrome DAF-FM DA. Scale bar for NO accumulation represents $60 \mu \mathrm{m}$. Data are expressed as mean \pm SE, with $n=3$. Different letters denote significant difference at $P \leq 0.05$ according to Duncan's multiple range tests

both abolished the effect of Spd on the NO content (Figs. 2c and 2d). Arasimowicz-Jelonek et al. (2009) indicated that the NOS-like and NR pathways are associated with PA-induced NO generation in cucumber leaves during drought stress. The present study suggests that Spd induced NO production through both the NOS-like and NR pathways in tomato leaves under chilling stress.
PAs can enhance $\mathrm{H}_{2} \mathrm{O}_{2}$ production via Put, Spd, or Spm catabolism (Su et al., 2006; Alcázar et al., 2010; Wimalasekera et al., 2011; Moschou et al., 2012; Pál et al., 2015). $\mathrm{H}_{2} \mathrm{O}_{2}$ plays a dual role in plants: at low concentrations, it serves as a signal molecule, playing a pivotal role in signal transduction network under various stress conditions (Tanou et al., 2009; Jiang et al., 2012; Lizárraga-Paulín et al., 2013); 
at high concentrations, it can lead to extensive cell injury or death (Quan et al., 2008). $\mathrm{H}_{2} \mathrm{O}_{2}$ and $\mathrm{NO}$ are two types of signaling molecules, the generation of which often occurs in short succession or in parallel, and they can act both synergistically and independently (Bright et al., 2006; Pasqualini et al., 2009) To determine whether PAs increase NO production by inducing $\mathrm{H}_{2} \mathrm{O}_{2}$ under chilling stress, we studied the effect of PAs on the $\mathrm{H}_{2} \mathrm{O}_{2}$ content under chilling stress and the $\mathrm{NO}$ content in tomato leaves pretreated with $\mathrm{CAT}$ ( an $\mathrm{H}_{2} \mathrm{O}_{2}$ scavenger) before the application of PAs. As shown in Fig. 3a, exogenous Spd resulted in an increased $\mathrm{H}_{2} \mathrm{O}_{2}$ content in tomato leaves compared to control. However, compared to control, there was no obvious change in $\mathrm{H}_{2} \mathrm{O}_{2}$ production with Put treatment. In accordance with our results, Iannone et al. (2013) indicated that Spd and $\mathrm{Spm}$ increased $\mathrm{H}_{2} \mathrm{O}_{2}$ content by enhancing PAO activity in tobacco tissues, whereas Put had little effect on $\mathrm{H}_{2} \mathrm{O}_{2}$ formation. Moschou et al. (2008) and Yoda et al. (2003) have suggested that $\mathrm{Spd}$ is catabolized by PAO to produce $\mathrm{H}_{2} \mathrm{O}_{2}$. The results reported here suggest that $\mathrm{H}_{2} \mathrm{O}_{2}$ can be generated via PA catabolic pathways induced by Spd treatment. However, the application of Put has no such effect. NO production induced by Spd was markedly reduced by CAT, but CAT did not affect the NO production with Put treatment (Fig. 3b). It was observed that $\mathrm{H}_{2} \mathrm{O}_{2}$ can activate calcium channels (Pei et al., 2000; Kwak et al., 2003); in turn, calcium transients could induce NO accumulation (BessonBard et al., 2008; Courtois et al., 2008). Taken together, our results suggest that $\mathrm{H}_{2} \mathrm{O}_{2}$ acts upstream of $\mathrm{NO}$ to enhance its production in tomato. Some studies have also shown that $\mathrm{H}_{2} \mathrm{O}_{2}$ can induce $\mathrm{NO}$ production (Bright et al., 2006; Zhang et al., 2007). However, opposite results were reported in other studies.
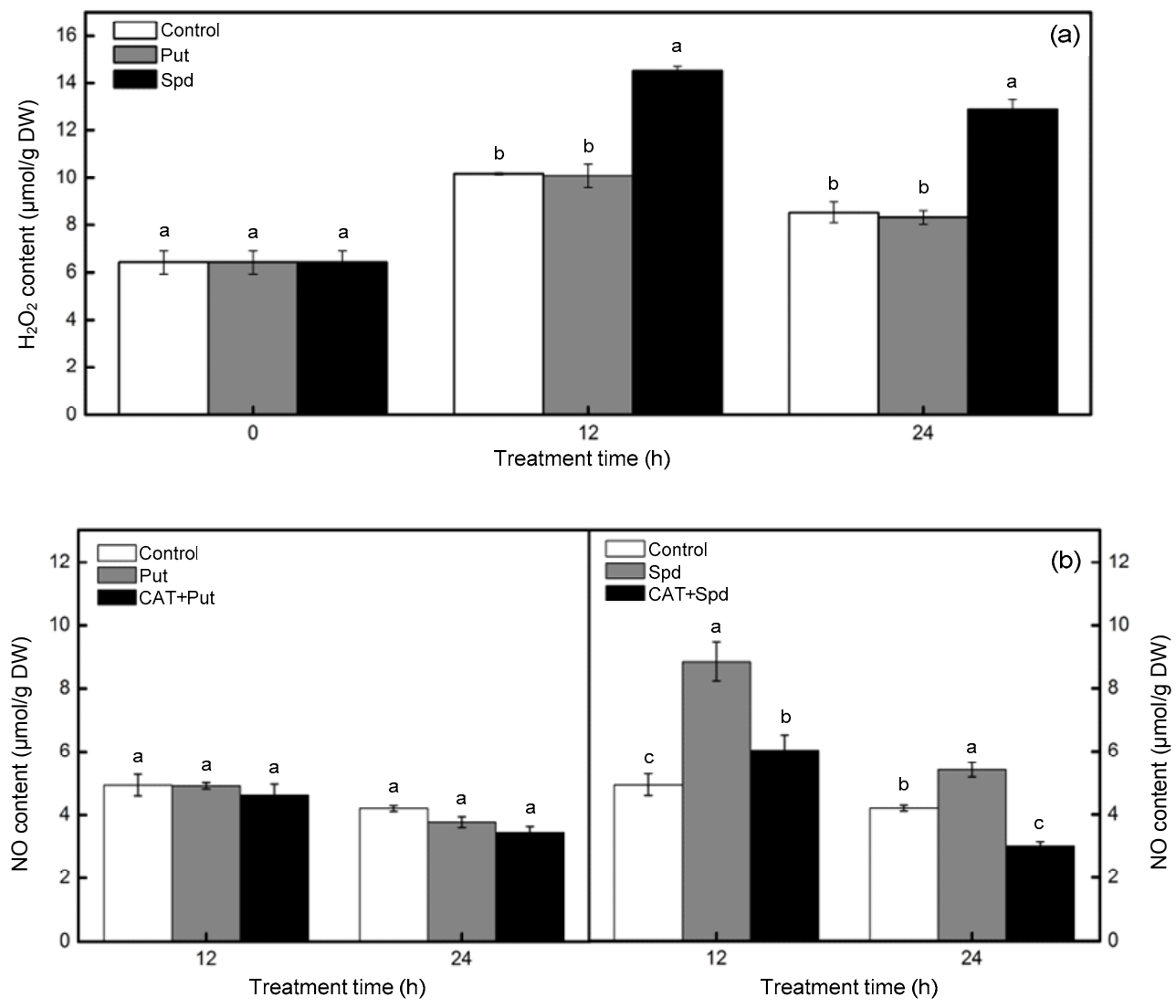

Fig. 3 Involvement of $\mathrm{H}_{2} \mathrm{O}_{2}$ in PA-induced NO generation

(a) Tomato seedlings were treated with PAs $(1 \mathrm{mmol} / \mathrm{L}$ Put and $1 \mathrm{mmol} / \mathrm{L} \mathrm{Spd})$ and distilled water (control). The samples were harvested for analysis of $\mathrm{H}_{2} \mathrm{O}_{2}$ content during chilling stress $\left(4^{\circ} \mathrm{C} ; 0,12\right.$, and $\left.24 \mathrm{~h}\right)$. (b) To further investigate the effect of Spd on NO content, some seedlings were treated with CAT (100 U/ml, $\mathrm{H}_{2} \mathrm{O}_{2}$ scavenger), and then sprayed with Put and Spd $12 \mathrm{~h}$ later, respectively. The seedlings' leaves for NO analysis were harvested at 12 and $24 \mathrm{~h}$ during chilling stress. Data are expressed as mean \pm SE, with $n=3$. Different letters denote significant difference at $P \leq 0.05$ according to Duncan's multiple range tests 
In tobacco leaves, $\mathrm{NO}$ treatment caused rapid $\mathrm{H}_{2} \mathrm{O}_{2}$ accumulation, but $\mathrm{H}_{2} \mathrm{O}_{2}$ treatment had no effect on NO generation (Pasqualini et al., 2009). This emphasizes that the linkage between $\mathrm{NO}$ and $\mathrm{H}_{2} \mathrm{O}_{2}$ in plants is a complicated issue to elucidate, due to the differences found in different species, the types of stress, or the experimental conditions used. Recent reports have indicated that exogenous NO induces PA generation (Fan et al., 2013; Li et al., 2014). As observed by Filippou et al. (2013), SNP treatment led to an enhancement in Put levels in Medicago truncatula plants. Similarly, in our previous studies, applying SNP increased the Put and Spm contents in tomato seedlings under chilling stress (data not shown). Hence, there may be a potential link between PAs and NO under environmental stresses.

\subsection{NO involved in Spd-induced chilling tolerance in tomato}

We have shown that Spd can induce increased production of NO; however, whether the NO induced by Spd is involved in Spd-enhanced stress tolerance remains unclear. The diamine Put protects against cell death and membrane damage; however, the higher PAs, Spd and Spm, are documented to be detrimental to cell viability, relying on the concentration and exposure time (Iannone et al., 2013). In our study, we found that the increase in the $F_{\mathrm{v}} / F_{\mathrm{m}}$ of tomatoes treated with Spd was reduced by NO synthesis inhibitors and scavengers, but SNP (NO donor) pretreatment could increase $F_{\mathrm{v}} / F_{\mathrm{m}}$ compared to control (Fig. 4). It is well known that the chlorophyll fluorescence parameter is used to detect and quantify chilling stress by means of changes induced in PSII. $F_{\mathrm{v}} / F_{\mathrm{m}}$, as a kind of chlorophyll fluorescence parameter, can be used as an important indicator of injury to PSII (Rizza et al., 2001; Lu et al., 2003; Tambussi et al., 2004; Baker, 2008; Liu et al., 2013; Zhou et al., 2015). Additionally, the present study showed that the application of Spd and SNP significantly decreased chilling-induced electrolyte leakage, compared to the chilling treatment alone. NO synthesis inhibitors and the scavenger both decreased the function of Spd (Fig. 5). These results showed that Spd can enhance chilling tolerance by inducing $\mathrm{NO}$ accumulation in tomato leaves. However, according to Groppa et al. (2008), NO induced by $\mathrm{Spm}$ is involved in wheat root growth inhibition. These contrasting results concerning whether PAs induce NO production or whether NO is induced by the physiological effects of PAs can be attributed to the use of different species, plant parts, and conditions.

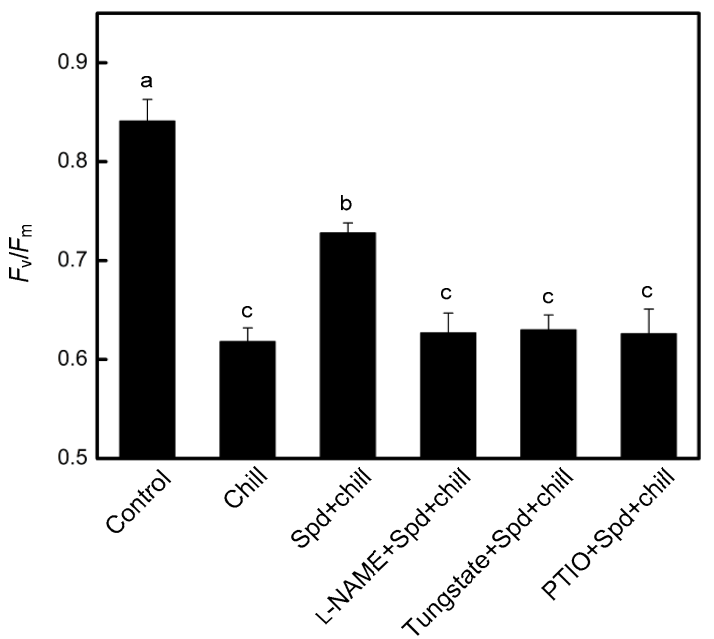

Fig. $4 F_{\mathrm{v}} / F_{\mathrm{m}}$ of different treatments in tomato leaves during chilling stress

Some seedlings were treated with $200 \mu \mathrm{mol} / \mathrm{L} \mathrm{SNP}$, and after $12 \mathrm{~h}$ exposed to chilling stress at $4{ }^{\circ} \mathrm{C}$ for $24 \mathrm{~h}$. Other seedlings were treated with distilled water, $200 \mu \mathrm{mol} / \mathrm{L}$ L-NAME, $200 \mu \mathrm{mol} / \mathrm{L}$ tungstate, or $200 \mu \mathrm{mol} / \mathrm{L}$ PTIO. After $12 \mathrm{~h}$, the seedlings were sprayed with $1 \mathrm{mmol} / \mathrm{L} \mathrm{Spd}$, and then exposed to chilling stress at $4{ }^{\circ} \mathrm{C}$ for $24 \mathrm{~h}$. The seedlings subjected to 25 or $4{ }^{\circ} \mathrm{C}$ for $24 \mathrm{~h}$ in phytotron were used as control and chilling treatment, respectively. $F_{\mathrm{v}} / F_{\mathrm{m}}$ was measured with a Dual-PAM 100 chlorophyll fluorometer at $24 \mathrm{~h}$ during chilling stress. Data are expressed as mean \pm SE, with $n=3$. Different letters denote significant difference at $P \leq 0.05$ according to Duncan's multiple range tests

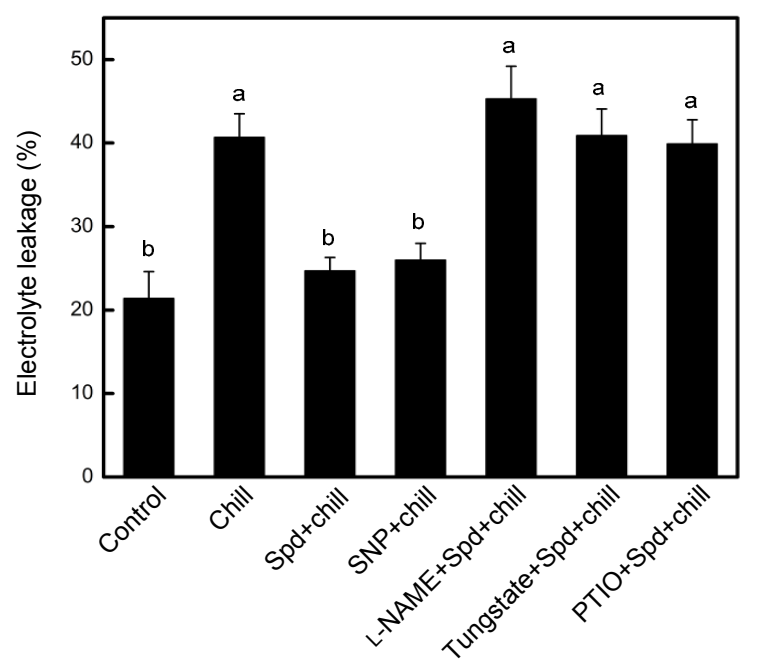

Fig. 5 Electrolyte leakage of different treatments in tomato leaves under chilling stress

The treatment details are as in the Fig. 4. Data are expressed as mean $\pm \mathrm{SE}$, with $n=3$. Different letters denote significant difference at $P \leq 0.05$ according to Duncan's multiple range tests 
We also further investigated the effects of $\mathrm{NO}$ inhibitor or scavenger treatment on the transcript levels and activities of antioxidant enzymes, including SOD, POD, CAT, and APX. In the present study, chilling treatment reduced both the activities and gene expressions of antioxidant enzymes, compared to those obtained with control. Exogenously applied Spd increased the transcript levels of antioxidant enzymes, as well as the activities of their relevant antioxidant enzymes, compared to chilling treatment. The increases in both transcripts and activities were suppressed by NO scavengers or inhibitors of NO biosynthesis (Figs. 6 and 7). NO has been suggested to increase the activities of antioxidant enzymes and up-regulate the expressions of the antioxidant genes in plants (Zhou et al., 2005; Zhang et al., 2007). It is well known that the antioxidant defense system plays vital roles in plants' tolerance to stressful conditions (Guan et al., 2009; Gill and Tuteja, 2010). Therefore, Spd could improve the chilling tolerance in tomato via the antioxidant system that is activated by NO. Moreover, previous studies have demonstrated that PAs could enhance the expressions and activities of antioxidant enzymes (Wi et al., 2006; Hussain et al., 2011). This phenomenon is generally attributed to their multifaceted nature (Velikova et al., 2000). Thus, it is concluded that Spd, as a kind of $\mathrm{PA}$, can enhance the expressions and activities of antioxidant enzymes by inducing NO production in tomato.

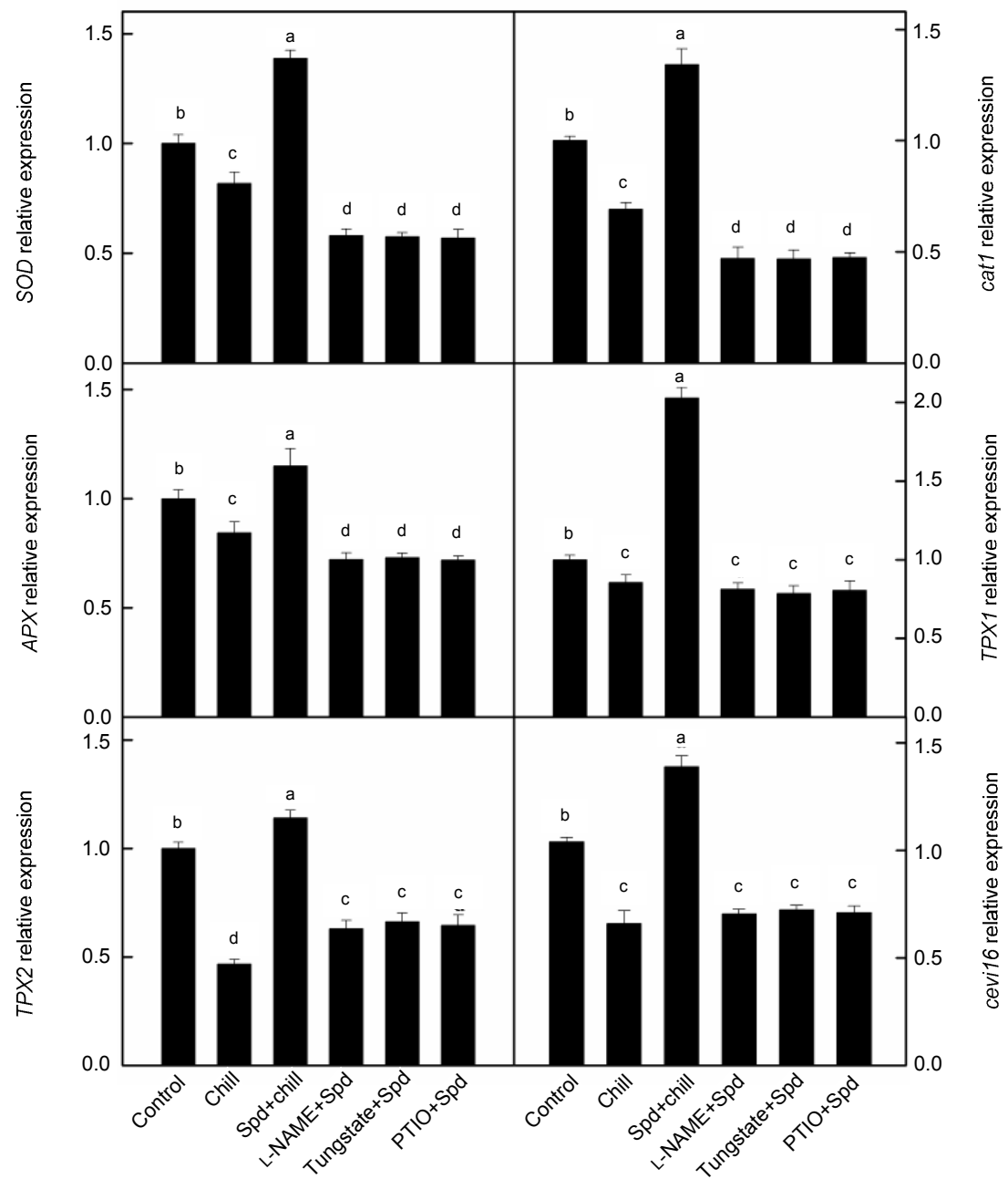

Fig. 6 Involvement of NO in Spd-induced expression of antioxidant genes in tomato leaves during chilling stress The tomato seedlings were pretreated with distilled water, $200 \mu \mathrm{mol} / \mathrm{L} \mathrm{L-NAME,} 200 \mu \mathrm{mol} / \mathrm{L}$ tungstate, or $200 \mu \mathrm{mol} / \mathrm{L}$ PTIO. After $12 \mathrm{~h}$, the seedlings were applied with $1 \mathrm{mmol} / \mathrm{L}$ Spd and exposed to chilling stress at $4{ }^{\circ} \mathrm{C}$ for $24 \mathrm{~h}$. The seedlings subjected to 25 or $4{ }^{\circ} \mathrm{C}$ for $24 \mathrm{~h}$ were used as control and chilling treatment, respectively. The seedlings' leaves for antioxidant genes with various treatments were harvested at $24 \mathrm{~h}$ during chilling stress. Data are expressed as mean $\pm \mathrm{SE}$, with $n=3$. Different letters denote significant difference at $P \leq 0.05$ according to Duncan's multiple range tests 


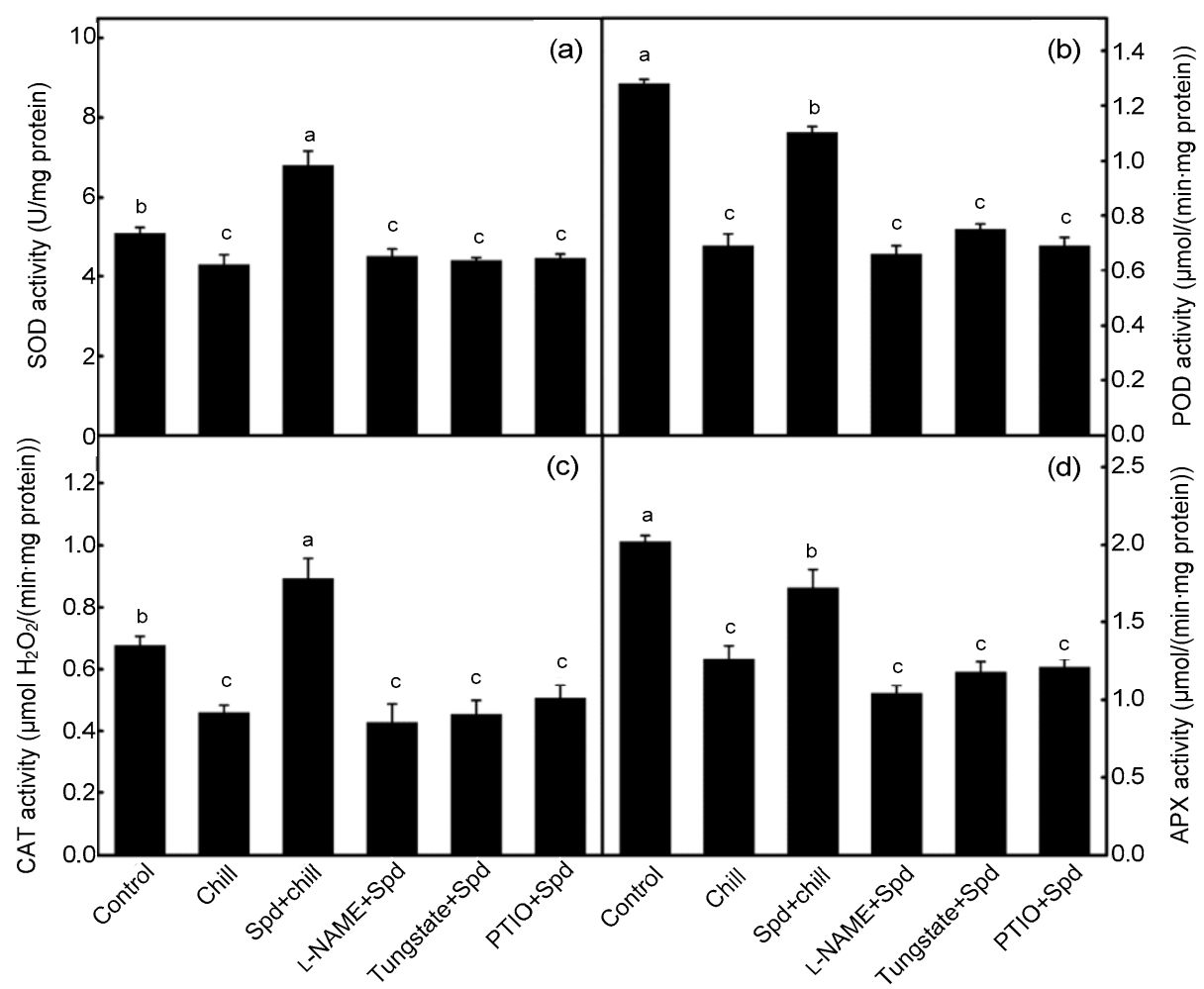

Fig. 7 Involvement of NO in Spd-induced antioxidant enzyme activity in tomato leaves under chilling stress The treatment details are as in the Fig. 6 . Data are expressed as mean \pm SE, with $n=3$. Different letters denote significant difference at $P \leq 0.05$ according to Duncan's multiple range tests

\section{Conclusions}

Based on our results, we suggest that Spd induces NO production directly through enhancing both NOSlike and NR activities or indirectly through inducing $\mathrm{H}_{2} \mathrm{O}_{2}$, which acts upstream of $\mathrm{NO}$ synthesis in tomato leaves under chilling stress. However, Put does not show such an effect. Moreover, NO participates in Spd-induced chilling tolerance in tomato, most probably via regulating the induction of antioxidant genes and enhancing the antioxidant activities.

\section{Compliance with ethics guidelines}

Qian-nan DIAO, Yong-jun SONG, Dong-mei SHI, and Hong-yan QI declare that they have no conflict of interest.

This article does not contain any studies with human or animal subjects performed by any of the authors.

\section{References}

Alcázar, R., Altabella, T., Marco, F., et al., 2010. Polyamines: molecules with regulatory functions in plant abiotic stress tolerance. Planta, 231(6):1237-1249.

http://dx.doi.org/10.1007/s00425-010-1130-0

Alemayehu, A., Zelinová, V., Bočová, B., et al., 2015. Enhanced nitric oxide generation in root transition zone during the early stage of cadmium stress is required for maintaining root growth in barley. Plant Soil, 390(1): 213-222.

http://dx.doi.org/10.1007/s11104-015-2397-5

Angelini, R., Tisi, A., Rea, G., et al., 2008. Involvement of polyamine oxidase in wound healing. Plant Physiol., 146(1):162-177.

http://dx.doi.org/10.1104/pp.107.108902

Arasimowicz-Jelonek, M., Floryszak-Wieczorek, J., Kubiś, J., 2009. Interaction between polyamine and nitric oxide signaling in adaptive responses to drought in cucumber. $J$. Plant Growth Regul., 28(2):177-186. http://dx.doi.org/10.1007/s00344-009-9086-7

Bais, H.P., Ravishankar, G.A., 2002. Role of polyamines in the ontogeny of plants and their biotechnological applications. Plant Cell Tissue Org. Cult., 69(1):1-34. http://dx.doi.org/10.1023/A:1015064227278

Baker, N.R., 2008. Chlorophyll fluorescence: a probe of photosynthesis in vivo. Annu. Rev. Plant Biol., 59:89-113. http://dx.doi.org/10.1146/annurev.arplant.59.032607.092759 
Besson-Bard, A., Pugin, A., Wendehenne, D., 2008. New insights into nitric oxide signaling in plants. Annu. Rev. Plant Biol., 59:21-39. http://dx.doi.org/10.1146/annurev.arplant.59.032607.092830

Besson-Bard, A., Astier, J., Rasul, S., et al., 2009. Current view of nitric oxide-responsive genes in plants. Plant Sci., 177(4):302-309.

http://dx.doi.org/10.1016/j.plantsci.2009.06.006

Bradford, M.M., 1976. A rapid and sensitive method for the quantitation of microgram quantities of protein utilizing the principle of protein-dye binding. Anal. Biochem., 72(1):248-254.

http://dx.doi.org/10.1016/0003-2697(76)90527-3

Bright, J., Desikan, R., Hancock, J.T., et al., 2006. ABAinduced NO generation and stomatal closure in Arabidopsis are dependent on $\mathrm{H}_{2} \mathrm{O}_{2}$ synthesis. Plant J., 45(1): 113-122. http://dx.doi.org/10.1111/j.1365-313X.2005.02615.x

Cakmak, I., Marschner, H., 1992. Magnesium deficiency and high light intensity enhance activities of superoxide dismutase, ascorbate peroxidase, and glutathione reductase in bean leaves. Plant Physiol., 98(4):1222-1227. http://dx.doi.org/10.1104/pp.98.4.1222

Cheng, L., Sun, R.R., Wang, F.Y., et al., 2012. Spermidine affects the transcriptome responses to high temperature stress in ripening tomato fruit. J. Zhejiang Univ.-Sci. B (Biomed. \& Biotechnol.), 13(4):283-297. http://dx.doi.org/10.1631/jzus.B1100060

Corpas, F.J., Barroso, J.B., Carreras, A., et al., 2006. Constitutive arginine-dependent nitric oxide synthase activity in different organs of pea seedlings during plant development. Planta, 224(2):246-254.

http://dx.doi.org/10.1007/s00425-005-0205-9

Courtois, C., Besson, A., Dahan, J., et al., 2008. Nitric oxide signalling in plants: interplays with $\mathrm{Ca}^{2+}$ and protein kinases. J. Exp. Bot., 59(2):155-163. http://dx.doi.org/10.1093/jxb/erm197

Cuevas, J.C., López-Cobollo, R., Alcázar, R., et al., 2008. Putrescine is involved in Arabidopsis freezing tolerance and cold acclimation by regulating abscisic acid levels in response to low temperature. Plant Physiol., 148(2): 1094-1105. http://dx.doi.org/10.1104/pp.108.122945

Delledonne, M., Xia, Y., Dixon, R.A., et al., 1998. Nitric oxide functions as a signal in plant disease resistance. Nature, 394(6693):585-588. http://dx.doi.org/10.1038/29087

del Río, L.A., Javier Corpas, F., Barroso, J.B., 2004. Nitric oxide and nitric oxide synthase activity in plants. Phytochemistry, 65(7):783-792. http://dx.doi.org/10.1016/j.phytochem.2004.02.001

Desikan, R., Griffiths, R., Hancock, J., et al., 2002. A new role for an old enzyme: nitrate reductase-mediated nitric oxide generation is required for abscisic acid-induced stomatal closure in Arabidopsis thaliana. PNAS, 99(25):1631416318. http://dx.doi.org/10.1073/pnas.252461999

Dickinson, B.C., Chang, C.J., 2011. Chemistry and biology of reactive oxygen species in signaling or stress responses.
Nat. Chem. Biol., 7(8):504-511.

http://dx.doi.org/10.1038/nchembio.607

Dordas, C., Hasinoff, B.B., Igamberdiev, A.U., et al., 2003. Expression of a stress-induced hemoglobin affects NO levels produced by alfalfa root cultures under hypoxic stress. Plant J., 35(6):763-770. http://dx.doi.org/10.1046/j.1365-313X.2003.01846.x

Esim, N., Atici, O., 2014. Nitric oxide improves chilling tolerance of maize by affecting apoplastic antioxidative enzymes in leaves. Plant Growth Regul., 72(1):29-38. http://dx.doi.org/10.1007/s10725-013-9833-4

Fan, H.F., Du, C.X., Guo, S.R., 2013. Nitric oxide enhances salt tolerance in cucumber seedlings by regulating free polyamine content. Environ. Exp. Bot., 86:52-59. http://dx.doi.org/10.1016/j.envexpbot.2010.09.007

Filippou, P., Antoniou, C., Fotopoulos, V., 2013. The nitric oxide donor sodium nitroprusside regulates polyamine and proline metabolism in leaves of Medicago truncatula plants. Free Radic. Biol. Med., 56:172-183. http://dx.doi.org/10.1016/j.freeradbiomed.2012.09.037

Finkel, T., Holbrook, J.N., 2000. Oxidants, oxidative stress and the biology of ageing. Nature, 408(6809):239-247. http://dx.doi.org/10.1038/35041687

Giannopolitis, C.N., Ries, S.K., 1977. Superoxide dismutases: I. Occurrence in higher plants. Plant Physiol., 59(2): 309-314. http://dx.doi.org/10.1104/pp.59.2.309

Gill, S.S., Tuteja, N., 2010. Reactive oxygen species and antioxidant machinery in abiotic stress tolerance in crop plants. Plant Physiol. Biochem., 48(12):909-930. http://dx.doi.org/10.1016/j.plaphy.2010.08.016

Gong, B., Li, X., Bloszies, S., et al., 2014. Sodic alkaline stress mitigation by interaction of nitric oxide and polyamines involves antioxidants and physiological strategies in Solanum lycopersicum. Free Radical Biol. Med., 71:36-48. http://dx.doi.org/10.1016/j.freeradbiomed.2014.02.018

Groppa, M.D., Benavides, M.P., 2008. Polyamines and abiotic stress: recent advances. Amino Acids, 34(1):35-45. http://dx.doi.org/10.1007/s00726-007-0501-8

Groppa, M.D., Rosales, E.P., Iannone, M.F., et al., 2008. Nitric oxide, polyamines and Cd-induced phytotoxicity in wheat roots. Phytochemistry, 69(14):2609-2615. http://dx.doi.org/10.1016/j.phytochem.2008.07.016

Guan, Y., Hu, J., Wang, X., et al., 2009. Seed priming with chitosan improves maize germination and seedling growth in relation to physiological changes under low temperature stress. J. Zhejiang Univ.-Sci. B (Biomed. \& Biotechnol.), 10(6):427-433. http://dx.doi.org/10.1631/jzus.B0820373

Guan, Y., Lin, H., Ma, L., et al., 2014. Nitric oxide and hydrogen peroxide are important signals mediating the allelopathic response of Arabidopsis to $p$-hydroxybenzoic acid. Physiol. Plant., 152(2):275-285. http://dx.doi.org/10.1111/ppl.12164

Guo, F.Q., Okamoto, M., Crawford, N.M., 2003. Identification of a plant nitric oxide synthase gene involved in hormonal signaling. Science, 302(5642): 100-103. http://dx.doi.org/ 10.1126/science. 1086770

Gupta, K.J., Fernie, A.R., Kaiser, W.M., et al., 2011. On the 
origins of nitric oxide. Trends Plant Sci., 16(3):160-168. http://dx.doi.org/10.1016/j.tplants.2010.11.007

Gupta, K., Dey, A., Gupta, B., 2013. Plant polyamines in abiotic stress responses. Acta Physiol. Plant., 35(7): 2015-2036. http://dx.doi.org/10.1007/s11738-013-1239-4

He, L., Nada, K., Kasukabe, Y., et al., 2002. Enhanced susceptibility of photosynthesis to low-temperature photoinhibition due to interruption of chill-induced increase of $S$-adenosylmethionine decarboxylase activity in leaves of spinach (Spinacia oleracea L.). Plant Cell Physiol., 43(2):196-206.

http://dx.doi.org/10.1093/pcp/pcf021

Hussain, S.S., Ali, M., Ahmad, M., et al., 2011. Polyamines: natural and engineered abiotic and biotic stress tolerance in plants. Biotechnol. Adv., 29(3):300-311. http://dx.doi.org/10.1016/j.biotechadv.2011.01.003

Iannone, M.F., Rosales, E.P., Groppa, M.D., et al., 2013. $\mathrm{H}_{2} \mathrm{O}_{2}$ involvement in polyamine-induced cell death in tobacco leaf discs. J. Plant Growth Regul., 32(4):745-757. http://dx.doi.org/10.1007/s00344-013-9341-9

Igarashi, K., Kashiwagi, K., 2000. Polyamines: mysterious modulators of cellular functions. Biochem. Biophys. Res. Commun., 271(3):559-564.

http://dx.doi.org/10.1006/bbrc.2000.2601

Jiang, Y.P., Cheng, F., Zhou, Y.H., et al., 2012. Hydrogen peroxide functions as a secondary messenger for brassinosteroids-induced $\mathrm{CO}_{2}$ assimilation and carbohydrate metabolism in Cucumis sativus. J. Zhejiang Univ.-Sci. B (Biomed. \& Biotechnol.), 13(10):811-823. http://dx.doi.org/10.1631/jzus.B1200130

Kusano, T., Yamaguchi, K., Berberich, T., et al., 2007. Advances in polyamine research in 2007. J. Plant Res., 120(3):345-350. http://dx.doi.org/10.1007/s10265-007-0074-3

Kwak, J.M., Mori, I.C., Pei, Z.M., et al., 2003. NADPH oxidase AtrbohD and AtrbohF genes function in ROSdependent ABA signaling in Arabidopsis. EMBO J., 22(11):2623-2633. http://dx.doi.org/10.1093/emboj/cdg277

Li, X., Gong, B., Xu, K., 2014. Interaction of nitric oxide and polyamines involves antioxidants and physiological strategies against chilling-induced oxidative damage in Zingiber officinale Roscoe. Sci. Hort., 170:237-248. http://dx.doi.org/10.1016/j.scienta.2014.03.026

Li, Z., Zhou, H., Peng, Y., et al., 2015. Exogenously applied spermidine improves drought tolerance in creeping bentgrass associated with changes in antioxidant defense, endogenous polyamines and phytohormones. Plant Growth Regul., 76(1):71-82. http://dx.doi.org/10.1007/s10725-014-9978-9

Liu, D.F., Zhang, D., Liu, G.Q., et al., 2013. Influence of heat stress on leaf ultrastructure, photosynthetic performance, and ascorbate peroxidase gene expression of two pear cultivars (Pyrus pyrifolia). J. Zhejiang Univ.-Sci. B (Biomed. \& Biotechnol.), 14(12):1070-1083. http://dx.doi.org/10.1631/jzus.B1300094

Lizárraga-Paulín, E.G., Miranda-Castro, S.P., Moreno-Martínez, E., et al., 2013. Maize seed coatings and seedling sprayings with chitosan and hydrogen peroxide: their influence on some phenological and biochemical behaviors. J. Zhejiang Univ.-Sci. B (Biomed. \& Biotechnol.), 14(2):87-96. http://dx.doi.org/10.1631/jzus.B1200270

Lu, C., Qiu, N., Wang, B., 2003. Salinity treatment shows no effects on photosystem II photochemistry, but increases the resistance of photosystem II to heat stress in halophyte Suaeda salsa. J. Exp. Bot., 54(383):851-860. http://dx.doi.org/10.1093/jxb/erg080

Martin-Tanguy, J., 2001. Metabolism and function of polyamines in plants: recent development (new approaches). Plant Growth Regul., 34(1):135-148. http://dx.doi.org/10.1023/A:1013343106574

Moschou, P.N., Paschalidis, K.A., Delis, I.D., et al., 2008. Spermidine exodus and oxidation in the apoplast induced by abiotic stress is responsible for $\mathrm{H}_{2} \mathrm{O}_{2}$ signatures that direct tolerance responses in tobacco. Plant Cell., 20(6): 1708-1724. http://dx.doi.org/10.1105/tpc.108.059733

Moschou, P.N., Wu, J., Cona, A., et al., 2012. The polyamines and their catabolic products are significant players in the turnover of nitrogenous molecules in plants. J. Exp. Bot., 63(14):5003-5015. http://dx.doi.org/10.1093/jxb/ers202

Mostofa, M.G., Yoshida, N., Fujita, M., 2014. Spermidine pretreatment enhances heat tolerance in rice seedlings through modulating antioxidative and glyoxalase systems. Plant Growth Regul., 73(1):31-44. http://dx.doi.org/10.1007/s10725-013-9865-9

Murphy, M.E., Noack, E., 1994. Nitric oxide assay using hemoglobin method. Methods Enzymol., 233:240-250. http://dx.doi.org/10.1016/S0076-6879(94)33027-1

Nakano, Y., Asada, K., 1981. Hydrogen peroxide is scavenged by ascorbate-specific peroxidase in spinach chloroplasts. Plant Cell Physiol., 22(5):867-880.

Nayyar, H., 2005. Putrescine increases floral retention, pod set and seed yield in cold stressed chickpea. J. Agron. Crop Sci., 191(5):340-345. http://dx.doi.org/10.1111/j.1439-037X.2005.00158.x

Neill, S.J., Desikan, R., Hancock, J.T., 2003. Nitric oxide signalling in plants. New Phytol., 159(1):11-35. http://dx.doi.org/10.1046/j.1469-8137.2003.00804.x

Neill, S.J., Bright, J., Desikan, R., et al., 2008. Nitric oxide evolution and perception. J. Exp. Bot., 59(1):25-35. http://dx.doi.org/10.1093/jxb/erm218

Ninnemann, H., Maier, J., 1996. Indications for the occurrence of nitric oxide synthases in fungi and plants and the involvement in photoconidiation of Neurospora crassa. Photochem. Photobiol., 64(2):393-398. http://dx.doi.org/10.1111/j.1751-1097.1996.tb02477.x

Pál, M., Szalai, G., Janda, T., 2015. Speculation: polyamines are important in abiotic stress signaling. Plant Sci., 237: 16-23. http://dx.doi.org/10.1016/j.plantsci.2015.05.003

Parvin, S., Lee, O.R., Sathiyaraj, G., et al., 2014. Spermidine alleviates the growth of saline-stressed ginseng seedlings through antioxidative defense system. Gene, 537(1): 70-78.

http://dx.doi.org/10.1016/j.gene.2013.12.021 
Pasqualini, S., Meier, S., Gehring, C., et al., 2009. Ozone and nitric oxide induce cGMP-dependent and -independent transcription of defence genes in tobacco. New Phytol., 181(4):860-870. http://dx.doi.org/10.1111/j.1469-8137.2008.02711.x

Patterson, B.D., MacRae, E.A., Ferguson, I.B., 1984. Estimation of hydrogen peroxide in plant extracts using titanium(IV). Anal. Biochem., 139(2):487-492. http://dx.doi.org/10.1016/0003-2697(84)90039-3

Pei, Z.M., Murata, Y., Benning, G., et al., 2000. Calcium channels activated by hydrogen peroxide mediate abscisic acid signalling in guard cells. Nature, 406(6797):731-734. http://dx.doi.org/10.1038/35021067

Planchet, E., Gupta, K.J., Sonoda, M., et al., 2005. Nitric oxide emission from tobacco leaves and cell suspensions: rate limiting factors and evidence for the involvement of mitochondrial electron transport. Plant J., 41(5):732-743. http://dx.doi.org/10.1111/j.1365-313X.2005.02335.x

Puyang, X.H., An, M.Y., Han, L., et al., 2015. Protective effect of spermidine on salt stress induced oxidative damage in two Kentucky bluegrass (Poa pratensis L.) cultivars. Ecotoxicol. Environ. Saf., 117:96-106. http://dx.doi.org/10.1016/j.ecoenv.2015.03.023

Quan, L.J., Zhang, B., Shi, W.W., et al., 2008. Hydrogen peroxide in plants: a versatile molecule of the reactive oxygen species network. J. Integr. Plant Biol., 50(1):2-18. http://dx.doi.org/10.1111/j.1744-7909.2007.00599.x

Rider, J.E., Hacker, A., Mackintosh, C.A., et al., 2007. Spermine and spermidine mediate protection against oxidative damage caused by hydrogen peroxide. Amino Acids, 33(2):231-240. http://dx.doi.org/10.1007/s00726-007-0513-4

Rizza, F., Pagani, D., Stanca, A.M., et al., 2001. Use of chlorophyll fluorescence to evaluate the cold acclimation and freezing tolerance of winter and spring oats. Plant Breed., 120(5):389-396. http://dx.doi.org/10.1046/j.1439-0523.2001.00635.x

Rockel, P., Strube, F., Rockel, A., et al., 2002. Regulation of nitric oxide (NO) production by plant nitrate reductase in vivo and in vitro. J. Exp. Bot., 53(366):103-110. http://dx.doi.org/10.1093/jexbot/53.366.103

Rosales, E.P., Iannone, M.F., Groppa, M.D., et al., 2012. Polyamines modulate nitrate reductase activity in wheat leaves: involvement of nitric oxide. Amino Acids, 42(2): 857-865. http://dx.doi.org/10.1007/s00726-011-1001-4

Sairam, R.K., Srivastava, G.C., 2002. Changes in antioxidant activity in sub-cellular fractions of tolerant and susceptible wheat genotypes in response to long term salt stress. Plant Sci., 162(6):897-904. http://dx.doi.org/10.1016/S0168-9452(02)00037-7

Scheible, W.R., Gonzalez-Fontes, A., Lauerer, M., et al., 1997. Nitrate acts as a signal to induce organic acid metabolism and repress starch metabolism in tobacco. Plant Cell, 9(5):783-798. http://dx.doi.org/10.1105/tpc.9.5.783

Shu, S., Yuan, L.Y., Guo, S.R., et al., 2012. Effects of exogenous spermidine on photosynthesis, xanthophyll cycle and endogenous polyamines in cucumber seedlings ex- posed to salinity. Afr. J. Biotechnol., 11(22):6064-6074. http://dx.doi.org/10.5897/AJB11.1354

Siddiqui, M.H., Al-Whaibi, M.H., Basalah, M.O., 2011. Role of nitric oxide in tolerance of plants to abiotic stress. Protoplasma, 248(3):447-455. http://dx.doi.org/10.1007/s00709-010-0206-9

Silveira, V., Santa-Catarina, C., Tun, N.N., et al., 2006. Polyamine effects on the endogenous polyamine contents, nitric oxide release, growth and differentiation of embryogenic suspension cultures of Araucaria angustifolia (Bert.) O. Ktze. Plant Sci., 171(1):91-98. http://dx.doi.org/10.1016/j.plantsci.2006.02.015

Song, Y., Diao, Q., Qi, H., 2015. Polyamine metabolism and biosynthetic genes expression in tomato (Lycopersicon esculentum Mill.) seedlings during cold acclimation. Plant Growth Regul., 75(1):21-32. http://dx.doi.org/10.1007/s10725-014-9928-6

Su, G.X., Zhang, W.H., Liu, Y.L., 2006. Involvement of hydrogen peroxide generated by polyamine oxidative degradation in the development of lateral roots in soybean. $J$. Integr. Plant Biol., 48(4):426-432. http://dx.doi.org/10.1111/j.1744-7909.2006.00236.x

Sun, H., Li, J., Song, W., et al., 2015. Nitric oxide generated by nitrate reductase increases nitrogen uptake capacity by inducing lateral root formation and inorganic nitrogen uptake under partial nitrate nutrition in rice. J. Exp. Bot., 66(9):2449-2459. http://dx.doi.org/10.1093/jxb/erv030

Tambussi, E.A., Bartoli, C.G., Guiamet, J.J., et al., 2004. Oxidative stress and photodamage at low temperatures in soybean (Glycine max L. Merr.) leaves. Plant Sci., 167(1): 19-26. http://dx.doi.org/10.1016/j.plantsci.2004.02.018

Tanou, G., Job, C., Rajjou, L., et al., 2009. Proteomics reveals the overlapping roles of hydrogen peroxide and nitric oxide in the acclimation of citrus plants to salinity. Plant $J_{., 60}$ 60):795-804. http://dx.doi.org/10.1111/j.1365-313X.2009.04000.x

Tanou, G., Ziogas, V., Belghazi, M., et al., 2014. Polyamines reprogram oxidative and nitrosative status and the proteome of citrus plants exposed to salinity stress. Plant Cell Environ., 37(4):864-885. http://dx.doi.org/10.1111/pce.12204

Tewari, R.K., Prommer, J., Watanabe, M., 2013. Endogenous nitric oxide generation in protoplast chloroplasts. Plant Cell Rep., 32(1):31-44. http://dx.doi.org/10.1007/s00299-012-1338-5

Thomas, R.L., Jen, J.J., Morr, C.V., 1982. Changes in soluble and bound peroxidase - IAA oxidase during tomato fruit development. J. Food Sci., 47(1):158-161. http://dx.doi.org/10.1111/j.1365-2621.1982.tb11048.x

Tian, X., Lei, Y., 2006. Nitric oxide treatment alleviates drought stress in wheat seedlings. Biol. Plant., 50(4): 775-778. http://dx.doi.org/10.1007/s10535-006-0129-7

Tun, N.N., Santa-Catarina, C., Begum, T., et al., 2006. Polyamines induce rapid biosynthesis of nitric oxide (NO) in Arabidopsis thaliana seedlings. Plant Cell Physiol., 47(3): 346-354. 
http://dx.doi.org/10.1093/pcp/pci252

Velikova, V., Yordanov, I., Edreva, A., 2000. Oxidative stress and some antioxidant systems in acid rain-treated bean plants: protective role of exogenous polyamines. Plant Sci., 151(1):59-66. http://dx.doi.org/10.1016/S0168-9452(99)00197-1

Verma, S., Mishra, S.N., 2005. Putrescine alleviation of growth in salt stressed Brassica juncea by inducing antioxidative defense system. J. Plant Physiol., 162(6):669-677. http://dx.doi.org/10.1016/j.jplph.2004.08.008

Wi, S.J., Kim, W.T., Park, K.Y., 2006. Overexpression of carnation $S$-adenosylmethionine decarboxylase gene generates a broad-spectrum tolerance to abiotic stresses in transgenic tobacco plants. Plant Cell Rep., 25(10):1111-1121. http://dx.doi.org/10.1007/s00299-006-0160-3

Wimalasekera, R., Tebartz, F., Scherer, G.F., 2011. Polyamines, polyamine oxidases and nitric oxide in development, abiotic and biotic stresses. Plant Sci., 181(5):593-603. http://dx.doi.org/10.1016/j.plantsci.2011.04.002

Xiong, J., Fu, G., Yang, Y., et al., 2012. Tungstate: is it really a specific nitrate reductase inhibitor in plant nitric oxide research? J. Exp. Bot., 63(1):33-41. http://dx.doi.org/10.1093/jxb/err268

Yamamoto, A., Shim, I.S., Fujihara, S., 2012. Chilling-stress responses by rice seedlings grown with different ammonium concentrations and its relationship to leaf spermidine content. J. Plant Biol., 55(3):191-197. http://dx.doi.org/10.1007/s12374-011-0072-9

Yamasaki, H., Cohen, M.F., 2006. NO signal at the crossroads: polyamine-induced nitric oxide synthesis in plants? Trends Plant Sci., 11(11):522-524. http://dx.doi.org/10.1016/j.tplants.2006.09.009

Yang, J.C., Zhang, J.H., Liu, K., et al., 2007. Involvement of polyamines in the drought resistance of rice. J. Exp. Bot., 58(6): $1545-1555$. http://dx.doi.org/10.1093/jxb/erm032

Yoda, H., Yamaguchi, Y., Sano, H., 2003. Induction of hypersensitive cell death by hydrogen peroxide produced through polyamine degradation in tobacco plants. Plant Physiol., 132(4):1973-1981. http://dx.doi.org/10.1104/pp.103.024737

Yoda, H., Hiroi, Y., Sano, H., 2006. Polyamine oxidase is one of the key elements for oxidative burst to induce programmed cell death in tobacco cultured cells. Plant Physiol., 142(1):193-206. http://dx.doi.org/10.1104/pp.106.080515

Zapata, P.J., Serrano, M., Pretel, M.T., et al., 2004. Polyamines and ethylene changes during germination of different plant species under salinity. Plant Sci., 167(4):781-788. http://dx.doi.org/10.1016/j.plantsci.2004.05.014

Zemojtel, T., Fröhlich, A., Palmieri, M.C., et al., 2006. Plant nitric oxide synthase: a never-ending story? Trends Plant Sci., 11(11):524-525. http://dx.doi.org/10.1016/j.tplants.2006.09.008

Zhang, A., Jiang, M., Zhang, J., et al., 2007. Nitric oxide induced by hydrogen peroxide mediates abscisic acid-induced activation of the mitogen-activated protein kinase cascade involved in antioxidant defense in maize leaves. New Phytol., 175(1):36-50. http://dx.doi.org/10.1111/j.1469-8137.2007.02071.x

Zhou, B., Guo, Z., Xing, J., et al., 2005. Nitric oxide is involved in abscisic acid-induced antioxidant activities in Stylosanthes guianensis. J. Exp. Bot., 56(422):3223-3228. http://dx.doi.org/10.1093/jxb/eri319

Zhou, R., Yu, X., Kjær, K.H., et al., 2015. Screening and validation of tomato genotypes under heat stress using $F_{\mathrm{v}} / F_{\mathrm{m}}$ to reveal the physiological mechanism of heat tolerance. Environ. Exp. Bot., 118:1-11.

http://dx.doi.org/10.1016/j.envexpbot.2015.05.006

\section{List of electronic supplementary materials}

Fig. S1 Effects of exogenous Put and Spd on leNR and leNOS1 relative expression in the leaves of tomato under chilling stress

Table S1 Gene accession numbers and primer sequences of tomato NR and NOS1 in this study

\section{中文概要}

\section{题 目: 多胺诱导产生的一氧化氮通过影响番茄幼苗抗氧 化系统抵御低温胁迫}

目 的: 研究多胺 (PA) 对低温胁迫下番茄幼苗中一氧化 氮 (NO) 产生的影响, 并探讨 NO 在 PA 诱导的 耐冷性中发挥的作用。

创新点: 在番茄幼苗中证明亚精胺 ( $\mathrm{Spd}$ ) 对 NO 产生的 影响及可能的作用途径, 且此作用与番茄耐低温 性有密切关系。

方 法: 通过检测氧合血红蛋白 $\left(\mathrm{HbO}_{2}\right)$ 向高铁血红蛋白 (metHb) 的转化进行 NO 含量测定; 通过与 NO 特异性荧光探针 (DAF-FMDA) 结合检测 NO 释 放量（图 1 和 2)。超氧化物歧化酶（SOD）活 性根据其抑制氮蓝四唑 (NBT) 在光下的还原作 用测定; 过氧化物酶 (POD) 活性通过测定酶提 取液与愈创木酚、过氧化氢 $\left(\mathrm{H}_{2} \mathrm{O}_{2}\right)$ 的混合物的 吸光度确定; 过氧化氢酶 (CAT) 活性根据 $\mathrm{H}_{2} \mathrm{O}_{2}$ 在 $240 \mathrm{~nm}$ 波长下的降解能力来测定; 抗坏血酸 过氧化物酶 (APX) 活性的测定参照 Nakano 和 Asada（1981）的方法在波长 $290 \mathrm{~nm}$ 下测定（图 6 和 7)。

结 论: 本研究的结果显示, Spd 诱导番茄叶片中 NO 的 产生可直接通过增加一氧化氮合酶 (NOS) 和硝 酸还原酶 (NR) 的活性实现 (图 2)。 $\mathrm{H}_{2} \mathrm{O}_{2}$ 作为 上游信号能够刺激 NO 的生成 (图 3)。NO 通过 增加抗氧化酶活性和相关基因的表达来参与 $\mathrm{Spd}$ 诱导的番茄耐冷性（图 6 和 7)。综上所述, Spd 诱导产生的 NO 在番茄响应低温胁迫中发挥重要 作用。

关键词: 番茄; 亚精胺; 耐冷性; 一氧化氮; 抗氧化酶 